\title{
Response of wheat varieties to different zinc application methods
}

\author{
Nauman Aziz ${ }^{1}$, Shazma Anwar ${ }^{1}$, Shaheen Kashmir ${ }^{2}$, Junaid Ahmad ${ }^{1 *}$, \\ Beena Saeed $^{3}$ and Shehryar Khan ${ }^{1}$ \\ 1. Department of Agronomy, The University of Agriculture, Peshawar-Pakistan \\ 2. Department of Botany, The University of Agriculture, Peshawar-Pakistan \\ 3. Department of Agriculture, University of Sawabi-Pakistan \\ *Corresponding author's email: Junaid.agri@aup.edu.pk \\ Citation \\ Nauman Aziz, Shazma Anwar, Shaheen Kashmir, Junaid Ahmad, Beena Saeed and Shehryar Khan. Response of \\ wheat varieties to different zinc application methods. Pure and Applied Biology. Vol. 8, Issue 1, pp489-495. \\ http://dx.doi.org/10.19045/bspab.2018.700207

\begin{tabular}{llll}
\hline \hline Received: 06/10/2018 & Revised: 06/12/2018 & Accepted: 08/12/2018 & Online First: 12/12/2018 \\
\hline \hline
\end{tabular}

\section{Abstract}

An experiment on response of different wheat varieties to zinc application methods was evaluated at Agriculture University Peshawar Pakistan in 2016-17. The experimental design was RCB with 3 replications. Zinc application methods (control, $1 \%$ foliar with $\mathrm{ZnSO}_{4}, 1 \%$ priming with $\mathrm{ZnSO}_{4}$, $15 \mathrm{~kg} \mathrm{ha}^{-1}$ soil application, $1 \%$ foliar with $\mathrm{ZnSO}_{4}+1 \%$ priming with $\mathrm{ZnSO}_{4}, 1 \%$ foliar with $\mathrm{ZnSO}_{4}$ $+15 \mathrm{~kg} \mathrm{ha}^{-1} \mathrm{Zn}$ application to soil, $1 \%$ priming with $\mathrm{ZnSO} 4+15 \mathrm{~kg} \mathrm{ha}^{-1} \mathrm{Zn}$ soil application, $1 \%$ foliar with $\mathrm{ZnSO}_{4}+1 \%$ priming with $\mathrm{ZnSO}_{4}+15 \mathrm{~kg} \mathrm{ha}^{-1} \mathrm{Zn}$ soil application) \& varieties (Atta Habib $\&$ Zincol) were used in the experiment. Plant height, spike $\mathrm{m}^{-2}$, grains spike ${ }^{-1}, 1000$ seed weight, biological yield and grain yield showed significant response to zinc application methods and varieties. Taller plant $(98.8 \mathrm{~cm})$, spikes $\mathrm{m}^{-2}$ (358), grains spike ${ }^{-1}(57), 1000$ seed weight $(49.1 \mathrm{~g})$, biological yield $\left(10067 \mathrm{~kg} \mathrm{ha}^{-1}\right)$ and grain yield $\left(4319.3 \mathrm{~kg} \mathrm{ha}^{-1}\right)$ were recorded in plots treated with $1 \%$ foliar with $\mathrm{ZnSO}_{4}+1 \%$ priming with $\mathrm{ZnSO}_{4}+15 \mathrm{~kg} \mathrm{ha}^{-1} \mathrm{Zn}$ soil application of $\mathrm{ZnSO}_{4}$. Considering wheat varieties plant height $(94 \mathrm{~cm})$, tillers $\mathrm{m}^{-2}(317)$, spikes $\mathrm{m}^{-2}(301)$, grains spike ${ }^{-}$ ${ }^{1}(52)$, biological yield $\left(9073.3 \mathrm{~kg} \mathrm{ha}^{-1}\right)$ and grain yield $\left(4103.5 \mathrm{~kg} \mathrm{ha}^{-1}\right)$ recorded from Zincol. It is concluded that Zincol wheat variety with application of $1 \%$ foliar with $\mathrm{ZnSO}_{4}+1 \%$ priming with $\mathrm{ZnSO}_{4}+15 \mathrm{~kg} \mathrm{ha}^{-1} \mathrm{Zn}$ soil application of $\mathrm{ZnSO}_{4}$ performed better in terms of yield and thus recommended for general cultivation.

Keywords: Foliar; Priming; Varieties; Zinc application; Zincol

\section{Introduction}

In cereals wheat is the most important crop worldwide. Among wheat producing countries Pakistan ranks $8^{\text {th }}$, contributes almost $3.17 \%$ wheat production of the world. In Pakistan wheat crop is a leading food grain and occupies central position in economy. In Pakistan during 2015-16 wheat is cultivated on about 8.66 million hectares with total production of 23.517 million tons [1]. While in Khyber Pakhtunkhwa it was cultivated on 0.758 million hectares with average production of $1607.5 \mathrm{~kg} \mathrm{ha}^{-1}$. Wheat, as a food crop is mostly used for its good taste and source of calories, proteins and vitamins. Low quality of wheat and flour-milling by-products are used as source of feed for livestock.

Micronutrients are used for growth and regulation of plant's vital physiological processes. They are necessary in low amounts, but equally important like macronutrients [2]. Deficiency of micronutrients in Pakistan is due to calcareous soils, high $\mathrm{pH}$, low organic matter, salt stress and imbalanced application of NPK fertilizers [3]. Zinc is one of the most important micronutrient in 
biological zones and is receiving more attention throughout world $[4,5]$. Deficiency of $\mathrm{Zn}$ affects about $1 / 3$ of the total world's populations $[6,7]$. In soils due to low dissolvability of $\mathrm{Zn}$ plant cell growth reduction and development is one of the $\mathrm{Zn}$ deficiency symptom [8]. In human beings $\mathrm{Zn}$ deficiency is very common especially in those countries with high consumptions of cereal-based foods. Therefore, there is a great need to improve cereal crops with adequate $\mathrm{Zn}$ nutrition. Deficiency of $\mathrm{Zn}$ is also a critical constraint to wheat production. In cereals based cultivated soils all over the world it is widely accepted that deficiency of $\mathrm{Zn}$ in soil is the most commonly occurring micronutrient deficiency. The unavailability of soil $\mathrm{Zn}$ resulting in severe losses in terms of economic and decreased plant growth and yield production.

Foliar application of different nutrients to plants is another option when deficiency of nutrient cannot be met properly by nutrients applications to the soil [4]. When the roots cannot provide the required nutrients to plant, in such circumstances foliar spraying of microelements is very helpful $[9,10]$. When zinc fertilizer is applied to crop at later stages, $\mathrm{Zn}$ deposition in grains particularly increases. Past studies conducted on $\mathrm{Zn}$ cleared that maximum accumulation of $\mathrm{Zn}$ take place during grain development stage and the concentration of $\mathrm{Zn}$ in wheat grains accumulates more at milky stage of grain development. From the foliar spray of $\mathrm{Zn}$ it has been shown that in the late growth stages like at milk and dough stage resulted in much more enhancement in grain $\mathrm{Zn}$ concentration than application of $\mathrm{Zn}$ at earlier growth stages when compared [11]. A potential problem is that increasing in $\mathrm{Zn}$ concentration in flour may affect negatively its processing traits [8]. $\mathrm{Zn}$ is more effective in increasing $\mathrm{Zn}$ concentration in seeds by its foliar application at all seed development stages. In seeds the highest $\mathrm{Zn}$ concentration can be achieved when applied at the first stages of development of seed [12]. Currently, increasing grain $\mathrm{Zn}$ concentration is most important global challenge in order to minimize $\mathrm{Zn}$ deficiency related health problems. Since wheat crop have very low amount of $\mathrm{Zn}$ in grains and growing wheat on $\mathrm{Zn}$ deficient soils reduces $\mathrm{Zn}$ concentration in $\mathrm{Zn}$. Hence foliar application of $\mathrm{Zn}$ to wheat is fundamentally important for both good crop productivity and better human health. Keeping in view the importance of $\mathrm{Zn}$ for better wheat production, this research study is designed to study the main and interactive effect of wheat varieties to different zinc application methods.

\section{Materials and methods}

Response of wheat varieties to different zinc application methods was evaluated at Agronomy Research Farm, The University of Agriculture, Peshawar during winter season 2016-17. The experiment consisted of these factors. Factor A; Zinc Application Methods, $\mathrm{Zn}_{1}=$ Control, $\mathrm{Zn}_{2}=1 \%$ foliar with $\mathrm{ZnSO}_{4}, \mathrm{Zn}_{3}=1 \%$ priming with $\mathrm{ZnSO}_{4}$, $\mathrm{Zn}_{4}=15 \mathrm{~kg} \mathrm{ha}^{-1} \mathrm{Zn}$ soil application, $\mathrm{Zn}_{5=} 1 \%$ foliar with $\mathrm{ZnSO}_{4+} 1 \%$ priming with $\mathrm{ZnSO}_{4}$, $\mathrm{Zn}_{6=} 1 \%$ foliar with $\mathrm{ZnSO}_{4+} 15 \mathrm{~kg} \mathrm{ha}^{-1} \mathrm{Zn}$ soil application, $\mathrm{Zn}_{7=1 \%}$ priming with $\mathrm{ZnsSO}_{4+} 15 \mathrm{~kg} \mathrm{ha}^{-1} \mathrm{Zn}$ soil application, $\mathrm{Zn}_{8}=1 \%$ foliar with $\mathrm{ZnSO}_{4+1} 1 \%$ priming with $\mathrm{ZnSO}_{4+} 15 \mathrm{~kg} \mathrm{ha}^{-1} \mathrm{Zn}$ soil application. Factor B; Wheat Varieties, $\mathrm{V}_{1}=$ Atta Habib, $\mathrm{V}_{2}=$ Zincol. All the treatment combinations were randomly allotted to the experimental units using randomized complete block design with 3 replications. Plot size was maintained $3 \mathrm{~m} \times 3 \mathrm{~m}$. For foliar application and $\mathrm{Zn}$ priming, $1 \%$ solution from $\mathrm{ZnSO}_{4} .7 \mathrm{H}_{2} \mathrm{O}$ source was prepared. The solution was diluted with water while keeping in view the treatments and volume to wet the plot area completely. The foliar $\mathrm{Zn}$ treatment was applied in the late afternoon within different growth stages. Wheat varieties Atta Habib and Zincol were sown at the rate of $120 \mathrm{~kg} \mathrm{ha}^{-1}$ with $30 \mathrm{~cm}$ $\mathrm{R}-\mathrm{R}$ distance. The nitrogen and phosphorus was applied at the rate of $120 \mathrm{~kg} \mathrm{ha}^{-1}$ and 90 $\mathrm{kg} \mathrm{ha}^{-1}$. Urea and DAP was used as a source of nitrogen and phosphorous. All of the 
phosphorous and half dose of nitrogen was applied at sowing time and the remaining dose was applied later at $2^{\text {nd }}$ irrigation. All other agronomic practices were kept normal and uniform for all the treatments.

\section{Statistical analysis}

Data was statistically analyzed [13] and means were computed using LSD test $(\mathrm{P}<$ $0.05)$.

Results

\section{Plant height (cm)}

Data on plant height of wheat as influenced by different zinc application methods and varieties are given in (Table 1). The data shows that zinc application methods and varieties shows significant affect plant height of wheat. Highest plant height (98.8 $\mathrm{cm})$ was recorded in plots which were treated with $1 \%$ foliar $+1 \%$ priming +15 $\mathrm{kg} \mathrm{ha}^{-1}$ soil application while the lowest was recorded with no zinc application. Similarly taller plants $(94 \mathrm{~cm})$ were recorded for

Table 1. Plant height $(\mathrm{cm})$, Number of productive tillers $\mathrm{m}^{-2}$, Number of spikes $\mathbf{m}^{-2}$, Number of grains spikes $^{-1}$ as affected by different zinc application methods and wheat varieties

\begin{tabular}{|c|c|c|c|c|}
\hline Zn Application Methods (Zn) & $\begin{array}{l}\text { Plant height } \\
(\mathrm{cm})\end{array}$ & $\begin{array}{l}\text { Productive } \\
\text { tillers } \mathbf{m}^{-2}\end{array}$ & $\underset{2}{\text { Spikes } \mathbf{m}^{-}}$ & $\begin{array}{l}\text { Grains } \\
\text { spikes }^{-1}\end{array}$ \\
\hline Control & $87.8 \mathrm{f}$ & $281 \mathrm{f}$ & $262 \mathrm{f}$ & $45 \mathrm{e}$ \\
\hline $1 \%$ foliar with $\mathrm{ZnSO}_{4}$ & $89.7 \mathrm{e}$ & $289 \mathrm{~g}$ & $276 \mathrm{e}$ & $48 \mathrm{~d}$ \\
\hline $1 \%$ priming with $\mathrm{ZnSO}_{4}$ & $90.5 \mathrm{de}$ & $297 \mathrm{e}$ & $275 \mathrm{e}$ & $54 \mathrm{c}$ \\
\hline $15 \mathrm{~kg} \mathrm{ha}^{-1}$ soil application & $90.0 \mathrm{e}$ & $282 \mathrm{~g}$ & $262 \mathrm{f}$ & $46 \mathrm{e}$ \\
\hline $\begin{array}{l}1 \% \text { foliar with } \mathrm{ZnSO}_{4+} 1 \% \text { priming with } \\
\mathrm{ZnSO}_{4}\end{array}$ & $92.2 \mathrm{~d}$ & $312 \mathrm{~d}$ & $297 d$ & $55 \mathrm{bc}$ \\
\hline $\begin{array}{c}1 \% \text { foliar with } \mathrm{ZnSO}_{4+} 15 \mathrm{~kg} \mathrm{ha}^{-1} \mathrm{Zn} \text { soil } \\
\text { application }\end{array}$ & $94.5 \mathrm{c}$ & $330 \mathrm{c}$ & $316 \mathrm{c}$ & $55 \mathrm{abc}$ \\
\hline $\begin{array}{l}1 \% \text { priming with } \mathrm{ZnsSO}_{4+} 15 \mathrm{~kg} \mathrm{ha}^{-1} \mathrm{Zn} \\
\text { soil application }\end{array}$ & $96.8 \mathrm{~b}$ & $358 \mathrm{~b}$ & $345 \mathrm{~b}$ & $56 \mathrm{ab}$ \\
\hline $\begin{array}{l}1 \% \text { foliar with } \mathrm{ZnSO}_{4+} 1 \% \text { priming with } \\
\mathrm{ZnSO}_{4+} 15 \mathrm{~kg} \mathrm{ha}^{-1} \mathrm{Zn} \text { soil application }\end{array}$ & $98.8 \mathrm{a}$ & $368 \mathrm{a}$ & $358 \mathrm{a}$ & $57 \mathrm{a}$ \\
\hline \multicolumn{5}{|l|}{ LSD $(0.05)$} \\
\hline \multicolumn{5}{|l|}{ Varieties $(\mathrm{V})$} \\
\hline Atta Habib & $91.0 \mathrm{~b}$ & $313.1 \mathrm{~b}$ & $296.7 \mathrm{ab}$ & $51.9 \mathrm{~b}$ \\
\hline Zincol & $94.0 \mathrm{a}$ & $317 \mathrm{a}$ & $301.6 \mathrm{a}$ & $52.8 \mathrm{a}$ \\
\hline LSD (0.05) & 0.88 & 2.84 & 3.09 & \\
\hline Interaction $(\mathrm{Zn} \times \mathrm{V})$ & ns & ns & ns & $\mathrm{ns}$ \\
\hline
\end{tabular}

\section{Number of spikes $\left(\mathrm{m}^{-2}\right)$}

Number of spikes per $\mathrm{m}^{2}$ of wheat as affected by various zinc application methods and varieties are given in (Table 1). The data shows that application methods of zinc and varieties effect significantly
Zincol and short stature plants were recorded for Atta Habib $(91 \mathrm{~cm})$. V x Zn was found non-significant.

\section{Number of productive tillers $\left(\mathrm{m}^{-2}\right)$}

Table 1 shows data on number of productive tillers per $\mathrm{m}^{2}$ of wheat as influenced by different zinc application methods. The data shows that zinc application methods and varieties significantly affected number of productive tillers $\mathrm{m}^{-2}$ of wheat. More number of productive tillers $\mathrm{m}^{-2}$ (368) were observed in plots which were treated with $1 \%$ foliar $+1 \%$ priming $+15 \mathrm{~kg} \mathrm{ha}^{-1}$ soil application while lower (281) were recorded with no zinc application. In case of varieties maximum number of tillers per $\mathrm{m}^{2}$ was recorded for Zincol (317) and lower were recorded for Atta Habib (313). The interaction of $\mathrm{v} \times \mathrm{Zn}$ was found nonsignificant. 
recorded for Zincol and lower (296) were recorded for Atta Habib. The combine effect of zinc on wheat varieties was found non-significant.

\section{Number of grains spike $\mathrm{e}^{-1}$}

Table 1 shows number of grains spike ${ }^{-1}$ of wheat as affected by different zinc application methods. The data shows that zinc application methods and varieties significantly affected number of grains spike $^{-1}$ of wheat. Higher number of grains spike $^{-1}$ (57) were recorded when treated with $1 \%$ foliar $+1 \%$ priming $+15 \mathrm{~kg} \mathrm{ha}^{-1}$ soil application while less (45) were recorded at no zinc application. Higher number of grains spike ${ }^{-1}$ (52.8) was recorded for Zincol and lower (51) were recorded for Atta Habib. The interaction of $\mathrm{V} \times \mathrm{Zn}$ was found non-significant.

\section{Thousand grain weight (g)}

Data regarding thousand seed weight of wheat as affected by various zinc application methods and varieties are given in (Table 2). The data shows that zinc application methods and varieties affected significantly thousand seed weight of wheat. Heavier grains (49.1 g) were recorded in plants which were treated with $1 \%$ foliar $+1 \%$ priming $+15 \mathrm{~kg} \mathrm{ha}^{-1}$ soil application while lighter grains (40.0 g) were recorded in no zinc applied plants. More thousand grains weight (46.1 g) was recorded for Zincol and lower (44.5 g) was recorded for Atta Habib. The interaction of varieties with zinc application methods was found non-significant.

\section{Biological yield $\left(\mathrm{kg} \mathrm{ha}^{-1}\right)$}

Biological yield of wheat as influenced by different zinc application methods are presented in (Table 2). The data shows that zinc application methods and varieties significantly response to biological yield of wheat. More biological yield $\left(10067 \mathrm{~kg} \mathrm{ha}^{-}\right.$ $\left.{ }^{1}\right)$ was recorded in plots which were treated with $1 \%$ foliar $+1 \%$ priming $+15 \mathrm{~kg} \mathrm{ha}^{-1}$ soil application while least $\left(7721 \mathrm{~kg} \mathrm{ha}^{-1}\right)$ was recorded with no zinc application. Higher biological yield (9073 kg ha-1) was recorded for Zincol and lower $\left(8728 \mathrm{~kg} \mathrm{ha}^{-}\right.$ $\left.{ }^{1}\right)$ was recorded for Atta Habib. The combined effect of $\mathrm{V} \times \mathrm{Zn}$ was found nonsignificant.

Table 2. Thousand grains weight (g), biological yield $\left(\mathrm{kg} \mathrm{ha}^{-1}\right)$, grain yield $\left(\mathrm{kg} \mathrm{ha}^{-1}\right)$ and Harvest index (\%) as affected by different zinc application methods and wheat varieties

\begin{tabular}{|c|c|c|c|c|}
\hline $\begin{array}{c}\text { Zn Application Methods } \\
\text { (Zn) }\end{array}$ & $\begin{array}{l}\text { Thousand grains } \\
\text { weight }(\mathrm{g})\end{array}$ & $\begin{array}{c}\text { biological } \\
\text { yield } \\
\left(\mathrm{kg} \mathrm{ha}^{-1}\right)\end{array}$ & $\begin{array}{l}\text { Grain yield } \\
\left(\mathrm{kg} \mathrm{ha}^{-1}\right)\end{array}$ & $\begin{array}{c}\text { Harvest index } \\
(\%)\end{array}$ \\
\hline Control & $40.0 \mathrm{a}$ & $7721 \mathrm{e}$ & $3771 \mathrm{e}$ & 48.8 \\
\hline $1 \%$ foliar with $\mathrm{ZnSO}_{4}$ & $44.0 \mathrm{e}$ & $8181 \mathrm{de}$ & $3856 \mathrm{de}$ & 47.2 \\
\hline $1 \%$ priming with $\mathrm{ZnSO}_{4}$ & $45.2 \mathrm{~d}$ & $8626 \mathrm{~cd}$ & $3894 \mathrm{~cd}$ & 45.4 \\
\hline $15 \mathrm{~kg} \mathrm{ha}^{-1}$ soil application & $42.2 \mathrm{f}$ & $7834 \mathrm{e}$ & $3841 \mathrm{de}$ & 49.1 \\
\hline $\begin{array}{l}1 \% \text { foliar with } \mathrm{ZnSO}_{4+} 1 \% \\
\text { priming with } \mathrm{ZnSO}_{4}\end{array}$ & $46.3 \mathrm{c}$ & $9155 b c$ & 3992 c & 44.1 \\
\hline $\begin{array}{l}1 \% \text { foliar with } \mathrm{ZnSO}_{4+} 15 \mathrm{~kg} \\
\text { ha }^{-1} \text { soil application }\end{array}$ & $47.3 \mathrm{~b}$ & $9654 a b$ & $4106 \mathrm{~b}$ & 42.7 \\
\hline $\begin{array}{l}1 \% \text { priming with } \mathrm{ZnsSO}_{4+} 15 \\
\mathrm{~kg} \mathrm{ha}^{-1} \text { soil application }\end{array}$ & $48.4 \mathrm{a}$ & 9965 a & $4193 \mathrm{~b}$ & 42.1 \\
\hline $\begin{array}{l}1 \% \text { foliar with } \mathrm{ZnSO}_{4+} 1 \% \\
\text { priming with } \mathrm{ZnSO}_{4+} 15 \mathrm{~kg} \\
\text { ha }^{-1} \text { soil application }\end{array}$ & $49.1 \mathrm{a}$ & $10067 \mathrm{a}$ & $4319 \mathrm{a}$ & 42.9 \\
\hline \multicolumn{5}{|l|}{ LSD $(0.05)$} \\
\hline \multicolumn{5}{|l|}{ Varieties (V) } \\
\hline Atta Habib & $44.5 \mathrm{~b}$ & $8728.4 \mathrm{~b}$ & $3890.1 \mathrm{~b}$ & $44.9 \mathrm{~b}$ \\
\hline Zincol & $46.1 \mathrm{a}$ & $9073.3 \mathrm{a}$ & $4103.5 \mathrm{a}$ & $45.7 \mathrm{a}$ \\
\hline LSD (0.05) & 0.38 & 315.49 & 49.7 & Ns \\
\hline Interaction $(\mathrm{Zn} \times \mathrm{V})$ & ns & ns & $*$ & Ns \\
\hline
\end{tabular}




\section{Grain yield ( $\mathrm{kg} \mathrm{ha}^{-1}$ )}

Data of grain yield of wheat as influenced by various zinc application methods and varieties are present in (Table 2). The data on grain yield of wheat shows significant response to zinc application method and varieties. More grain yield (4319 $\mathrm{kg} \mathrm{ha}^{-1}$ ) was recorded in those plots which were treated with $1 \%$ foliar $+1 \%$ priming +15 $\mathrm{kg} \mathrm{ha}^{-1}$ soil application while lower (3771 $\mathrm{kg} \mathrm{ha}{ }^{-1}$ ) was recorded with no zinc application. More grain yield $\left(4103 \mathrm{~kg} \mathrm{ha}^{-}\right.$ $\left.{ }^{1}\right)$ was recorded for Zincol and lower (3890 $\mathrm{kg} \mathrm{ha}^{-1}$ ) was recorded for Atta Habib. The interaction of $\mathrm{V} \times \mathrm{Zn}$ was found significant.

\section{Harvest index (\%)}

The impact of different zinc application methods and varieties on harvest index of wheat is shown in (Table 2). The data of different zinc application methods shows significant impact on harvest index of wheat. Maximum harvest index $(49.1 \%)$ was observed at $15 \mathrm{~kg} \mathrm{ha}^{-1} \mathrm{ZnSo}_{4}$ soil application while minimum $(42.1 \%)$ was recorded in those plots where $1 \%$ priming with $\mathrm{ZnSO}_{4}+15 \mathrm{~kg} \mathrm{ha}^{-1}$ soil application was applied. Varieties showed no profound impact on harvest index of wheat. The interaction of $\mathrm{V} \times \mathrm{Zn}$ was found nonsignificant.

\section{Discussion}

In terms of literature view collected for comparison and clarifications, the results achieved in the previous chapter are briefly discussed here.

Different application methods of zinc and significantly affected the plant height of wheat varieties. Highest plant height was observed in those plots which were treated with $1 \%$ foliar $+1 \%$ priming $+15 \mathrm{~kg} \mathrm{ha}^{-1}$ soil application while the lowest was recorded at no zinc application. This might me due to that zinc enhanced the growth and development of crop which resulted in taller plant. [14] Also reported the similar result that application of zinc increased plant height of wheat. Taller plants were recorded for Zincol and small stature plants were recorded for Atta Habib variety. Our results are in line with [15] who observed that maximum plant height was recorded in different varieties with zinc application.

Productive tillers $\mathrm{m}^{-2}$ of wheat was improved significantly in result of different zinc application methods. Similarly in case of varieties the effect of productive tillers per $\mathrm{m}^{2}$ was found significant. More number of productive tillers $\mathrm{m}^{-2}$ were recorded in those plots treated with $1 \%$ foliar $+1 \%$ priming $+15 \mathrm{~kg} \mathrm{ha}^{-1}$ soil application while least were recorded with no zinc application. [16] Observed that foliar application of zinc increased the number of tillers $\mathrm{m}^{-2}$. While in case of varieties more number of productive tillers $\mathrm{m}^{-2}$ was recorded for Zincol and less were recorded for Atta Habib. The difference in productive tillers $\mathrm{m}^{-2}$ might be due to different genetic make-up of the varieties. However our results are in contradiction with [17] who observed that higher tiller $\mathrm{m}^{-}$ ${ }^{2}$ was recorded in different varieties with zinc application.

Data showed that zinc application methods have significant impact on number of spike $\mathrm{m}^{-2}$ of wheat varieties. Higher number of spikes $\mathrm{m}^{-2}$ were recorded in those plots which were treated with $1 \%$ foliar $+1 \%$ priming $+15 \mathrm{~kg} \mathrm{ha}^{-1}$ soil application while least were recorded at no zinc application. Our results are in line with [18] who reported maximum number of spike $\mathrm{m}^{-2}$ zinc application methods. More number of spikes $\mathrm{m}^{-2}$ were recorded for Zincol and the least were recorded for Atta Habib. [19] Reported that number of spike $\mathrm{m}^{-2}$ of different varieties increased positively with the application of zinc.

Zinc application methods and varieties significantly affected number of grains spike $^{-1}$ of wheat. More grains spike ${ }^{-1}$ was recorded when treated with $1 \%$ foliar $+1 \%$ priming $+15 \mathrm{~kg} \mathrm{ha}^{-1}$ soil application while least were recorded with no zinc application. The increase in number of grains per spike may be due to high availability of zinc and the crop efficient used zinc. These results are in line with those of [20] who reported that application of different methods of zinc enhances the 
number of grains spike ${ }^{-1}$. More number of grains spike ${ }^{-1}$ were recorded for Zincol and less recorded for Atta Habib. Probable reason for this is that different varieties have different genetical potential to use zinc efficiently. These results are in line with those of [20], who found that application of different methods of zinc to different varieties enhances the number of grains spike ${ }^{-1}$.

Data showed the impact of zinc application methods and varieties on thousand grains weight of wheat. More thousand grains weight was recorded when treated with $1 \%$ foliar $+1 \%$ priming $+15 \mathrm{~kg} \mathrm{ha}^{-1}$ soil application while least was recorded with no zinc application. This increase might be due to maximum amount of dry matter accumulation in seeds of the wheat because of high concentration of zinc. Similar results are recorded by [21], who found that application of zinc produced heavier grains. Heavier grains weight was recorded for Zincol and least was recorded for Atta Habib. [19] Also reported that Zinc application significantly increased thousand grains weight of wheat varieties.

Biological yield of wheat was significantly affected by different zinc application methods. More biological yield was recorded in plots which were treated with $1 \%$ foliar $+1 \%$ priming $+15 \mathrm{~kg} \mathrm{ha}^{-1}$ soil application while least was recorded in no Zinc application. The reason for increase in biological yield might be that zinc application increased vegetative growth of the plant which resulted in greater biomass accumulation. Our results are in line with the result of [11] who reported that the unavailability of zinc may contribute to growth reduction in terms of lesser biomass production. More biological yield was recorded for Zincol and less was recorded for Atta Habib. The probable reason for the better response is that different varieties respond differently to zinc application method.

Grain yield of wheat varieties was affected by different application methods of zinc More grain yield was recorded with $1 \%$ foliar $+1 \%$ priming $+15 \mathrm{~kg} \mathrm{ha}^{-1}$ soil application method while less was recorded with no zinc application. Higher grain yield was oberved for Zincol and least was recorded for Atta Habib. This might be due to the fact that different varieties have different genetic make-up and hence respond differently to different zinc application method. [22] Also reported that zinc application methods increased the grains yield of wheat significantly.

The different zinc application methods showed significant impact on harvest index of wheat. Higher harvest index was recorded at $15 \mathrm{~kg} \mathrm{~h}^{-1}$ soil application while minimum was recorded in those plots where $1 \%$ priming with $\mathrm{ZnSO}_{4}+15 \mathrm{~kg}$ ha $^{-}$ ${ }^{1}$ soil application was applied. Our results are in line with those of [23] who reported maximum harvest index for higher dose of zinc. While varieties showed nonsignificant impact on harvest index.

\section{Conclusion}

It is concluded from the above finding that Zinc application method of $1 \%$ foliar +1 $\%$ priming $+15 \mathrm{~kg} \mathrm{ha}^{-1}$ soil $\mathrm{Zn}$ application produced higher grain yield of wheat. Zincol variety produced more productive tiller $\mathrm{m}^{-2}$, spike per $\mathrm{m}^{2}$, and 1000 seed weight, grains spike ${ }^{-1}$ and grain yield as compared to Atta Habib. Variety Zincol and Zinc application method consisting of $1 \%$ foliar with $\mathrm{ZnSO}_{4}+1 \%$ priming with $\mathrm{ZnSO}_{4}+15 \mathrm{~kg} \mathrm{ha}^{-1}$ soil application is recommended for achieving maximum yield and yield components of wheat.

\section{Authors' contributions}

Conceived and designed the experiments: $\mathrm{N}$ Aziz \& $S$ Anwar, Performed the experiments: N Aziz, Analyzed the data: N Aziz, S Anwar \& J Ahmad, Contributed materials/ analysis/ tools: S Kashmir, B Saeed \& S Khan, Wrote the paper: S Anwar \& J Ahmad.

\section{References}

1. MNFSR (2016). Ministry of national food security \& research; Agricultural Satistics, Govt. PK. Islamabad.

2. Bharti KN, Pandey D, Shankhdhar PC, Srivastava \& Shankhdhar SC (2013). Improving nutritional quality of wheat 
through soil and foliar zinc application. Plant Soil Environ 59(8): 348-352.

3. Hafeez B, Khanif YM \& Saleem M (2013). Role of zinc in plant nutrition. Amr J Exp Agri 3(2): 374-391.

4. Cakmak I (2008). Enrichment of cereal grains with zinc: Agronomic or genetic biofortification. Plant Soil 302: 1-17.

5. Kabata PA \& Pendias H (2011). Trace elements in soils and plants. CRC. Press, Boca Raton. Fla. USA.

6. Habib M (2009). Effect of foliar application of zinc and iron on wheat yield and quality. Afric J Biotech 8(24): 67956798.

7. Muyhaura CD, Musyimi IA \& Okello SV (2010). Effective microorganisms and their influence on growth and yield of pigweed (Amaranthus dubians). J Agr Bio Sci 5: 17-30.

8. Gomez BH, Abugalieva A, Morgoulfov A, Abdullayev K, Bekenova L, Yessimbekova, Sereda MG, Shpigun S, Tsygankov V, Zelenskiy Y, Pena RI \& Cakmak I (2010). Phenotypic correlations, G x E interactions and broad sense heritability analysis of grain and flour quality characteristics in high latitude spring bread wheat from Kazakhstan and Siberia. Euphytica 171: 23-38.

9. Kinaci E \& Gulmezoglu N (2007). Grain yield and yield components of triticale upon application of different foliar fertilizers. Interciencia 32(9): 624-628.

10. Babaeian M, Tavassoli A, Ghanbari A, Esmaeilian Y \& Fahimifard M (2011). Effects of foliar micronutrient application on osmotical adjustments, grain yield and yield components in sunflower under water stress at three stages. African $J$ Agric Res 6(5): 1204-1208.

11. Cakmak I (2012). Zinc fertilizer strategy for improving yield: Zinc deficiency represents a common micronutrient deficiency problem in human populations. Fluid J 20(1): 4-6.

12. Levent I, Yilmaz A, Taban S, Eker S, Torun B \& Cakmak I (2006). Phytic acid and phosphorus concentrations in seeds of wheat cultivars grown with and without zinc fertilization. Plant Nutr 25: 113-127.

13. Steel RGD \& Torrie JH (1984). Principles and procedure of statistics 2nd edi Mc, Graw Hill, New York.

14. Massoud AM, Abou-Zied MY \& Bakry MA (2005). Response of pea plants grown in clay soil to micronutrients and Rhizobium-inoculation. Egypt J Appl Sci 20: 9-346.

15. Johnson MF \& Susan JB (2011). The effect of zinc levels and wheat resistance on the Russian wheat aphid, Diuraphisnoxia. J Kansas Ento Soci 74(1): 49-55.

16. Nadim MA, Awan I, Baloch MS, Khan N \& Naveed K (2013). Micronutrient use efficiency in wheat as affected by different application methods. Pak $J$ Bot 45(3): 887-892.

17. Heidarian A, Kord R, Mostafavi K, Lak AP \& Mashhadi FA (2011). Investigating $\mathrm{Fe}$ and $\mathrm{Zn}$ foliar application on yield and its components of soybean (Glycine max L.) at different growth stages. Agric. Biotech. Sust Dev 3(9): 189-197.

18. Khalid SM, Bakht J \& Khan AB (2004). Effect of zinc application on the yield and yield components of wheat. Sarhad J Agric 20 (3): 277-280.

19. Mann RA, Jehangir WA \& Masih I (2004). Improving crop and water productivity of rice-wheat system in Punjab, Pakistan. In Proceedings of the 4th Int. Crop Sci. Congress, Brisbane.

20. Bakht J, Shafi M, Zubair M, Khan MA, Shah Z (2010). Effect of foliar vs. soil application of zinc on yield and yield components of wheat varieties. Pak J Bot 42(4): 2737-2745.

21. Ananda A \& Patil BN (2005). Influence of zinc, iron and time of nitrogen application on growth, yield and quality of durum wheat. J Agric Sci 18 (3): 599- 603.

22. Moghadam MJ, Sharifabad HH, Noormohamadi G, Motahar SYS \& Siadat SA (2012). The effect of zinc, boron and copper foliar application on yield and yield components in wheat (Triticum aestivum L.). Ani Bio Res 3(8): 38753884 .

23. Al-Abdulsalam MA (1997). Influence of nitrogen fertilization on the growth and yield of wheat (Triticum aestivum L.). Arab Gulf J Sci Res 15(3): 647-660. 